\section{The Effect of Irrigation on Terbacil Tolerance in Field-grown Strawberry}

\author{
Steven B. Polter ${ }^{1}$, Douglas Doohan ${ }^{2}$, and Joseph C. Scheerens ${ }^{2}$
}

AdDitional INDEX wORDs. Fragaria ananassa, weed control, 5-chloro-3-(1,1-dimethylethyl)-6-methyl-2,4-(1H, $1 H)$-pyrimidinedione, Sinbar

SUMMARY. Field experiments were conducted in newly planted strawberry (Fragaria $\times$ ananassa) with terbacil applied at rates of 0 to $6.4 \mathrm{oz} /$ acre a.i. either 4 days after planting but before appearance of new growth, or at the three-leaf stage. Irrigation of 0.4 inch was applied to half of the plots immediately after application of terbacil. Injury was greater when terbacil was applied before new growth than when applied at the three-leaf stage. Injury symptoms increased linearly with terbacil rate. Irrigation immediately following terbacil application reduced injury relative to non-irrigated plots. Weed control was reduced when terbacil was applied at the three-leaf stage than when applied before new growth. Irrigation did not reduce weed control. Herbicide injury symptoms were not detected the spring following terbacil application. Fruit yield was not affected by herbicide and irrigation treatments applied the previous year. The combination of low rates of terbacil, $0.8-1.6 \mathrm{oz} /$ acre a.i., followed by irrigation to remove the herbicide from foliage is a safe option that growers can use to improve weed control and reduce hand weeding costs in the planting year.

W eed control in strawberry production is a major cultural problem faced by growers in their efforts to produce a profitable crop. Options for weed control in strawberry includes mechanical cultivation, hand removal, mulching, fumigants and herbicides. Of these options, the use of herbicides is commonly practiced and cost-effective. However, few selective herbicides that can be applied directly to strawberry plants are registered, and those available do not control all weeds. The time interval during which herbicides can be safely applied and provide acceptable control is short. Once applied most herbicides are effective for only a few weeks. Risk of injury to strawberry is the greatest

$\overline{\text { Department of Horticulture and Crop Science, The }}$ Ohio State University, Ohio Agricultural Research and Development Center, 1680 Madison Ave., Wooster, $\mathrm{OH} 44691$.

Manuscript number HCS03-XX. Salaries and research support provided in part by State and Federal funds appropriated to the Ohio Agricultural Research and Development Center, The Ohio State University. Work was also supported by The Ohio Fruit Grower's Society. Use of trade names does not imply endorsement or the products named nor criticism of similar products not named.

We would like to acknowledge the contributions of Polter Berry Farm Inc., J.Y. Elliott, T.A. Koch, B.L. Bishop, and E.I. Du Pont De Nemours and Company, Agricultural Products, Wilmington, Del., for gift of Sinbar ${ }^{\circledR}$

${ }^{1}$ Graduate Research Assistant.

${ }^{2}$ Associate Professor. limitation to the use of some herbicides (Pritts and Handley, 1998).

Terbacil is one of the most effective herbicides labeled for use in strawberry although it can injure plants and reduce vigor. Established and actively growing strawberry plants are particularly susceptible to the herbicide (Pritts and Handley, 1998). The extent of damage to strawberry is proportional to the rate of terbacil applied (Ahrens, 1982; Lindstrom and Swartz, 1987; Masiunuas and Weller, 1986; Weller, 1984). Injury following terbacil application to strawberry foliage and soil can be severe with symptoms such as interveinal yellowing, scorched leaves, and necrosis. Crop injury due to root uptake alone includes yellow to necrotic leaf margins and yellow veins (Huffman, 1999). Absorption of terbacil through the leaf is thought the herbicide (Barrentine and Warren, 1970); however, injury of strawberry to play only a minor role in uptake of resulting from foliar uptake can be severe. When terbacil was applied to greenhouse grown strawberry, injury resulting from application to leaves only was greater than application exclusively to the roots (Polter et al., 2004). Therefore, it appears that uptake of terbacil by strawberry foliage is a significant factor in the severity of symptoms following a broadcast application.

Until recently, the Sinbar label (E.I. du Pont de Nemours \& Co., Crop Protection, Wilmington, Del.) prevented terbacil use in newly planted strawberry, even though many studies had shown that low rates applied to young plants resulted in little or no injury (DuPont, 1992). Sinbar, the only commercial source of terbacil, is an $80 \%$ wettable powder formulation; 8 oz of Sinbar contains $6.4 \mathrm{oz}$ of terbacil. When terbacil was applied at $2 \mathrm{oz} /$ acre, 4 weeks after planting and again in August, it did not injure the crop (Ahrens, 1982). However, a single application 4 weeks after planting at 4 or $8 \mathrm{oz} /$ acre caused injury of 2.3 and 5.0 , respectively, on a scale of $0-10$, where $0=$ no injury and 10 $=$ death. However, these treatments did not reduce the number of rooted runners or yield. In contrast, when terbacil was applied immediately after planting at a rate of $4 \mathrm{oz} /$ acre and irrigation was used to incorporate the herbicide, injury was not observed (Weller, 1984). When the application rate was increased to $8 \mathrm{oz} /$ acre, yield declined (Weller, 1984).

Even though slight damage to young strawberry plants may be acceptable, methods to prevent or reduce injury when terbacil is used in the planting year would be very beneficial. Irrigation applied immediately after terbacil application has been suggested as a practice that reduces injury (Huffman, 1999; Pritts and Handley, 1998). However, there has been no formal investigation to document the benefits of irrigation after terbacil application. Our

\begin{tabular}{llll}
\hline $\begin{array}{l}\text { Units } \\
\begin{array}{l}\text { To convert U.S. to SI, } \\
\text { multiply by }\end{array}\end{array}$ & U.S. unit & SI unit & $\begin{array}{l}\text { To convert SI to U.S., } \\
\text { multiply by }\end{array}$ \\
\hline 0.3048 & $\mathrm{ft}$ & $\mathrm{m}$ & 3.2808 \\
0.0929 & $\mathrm{ft}^{2}$ & $\mathrm{~m}^{2}$ & 10.7639 \\
9.3540 & gal/acre & $\mathrm{L} \cdot \mathrm{ha}^{-1}$ & 0.1069 \\
2.5400 & inch $(\mathrm{es})$ & $\mathrm{cm}$ & 0.3937 \\
1.1209 & $\mathrm{lb} / \mathrm{acre}$ & $\mathrm{kg} \cdot \mathrm{ha}^{-1}$ & 0.8922 \\
28.3495 & $\mathrm{oz}$ & $\mathrm{g}$ & 0.0353 \\
0.0701 & $\mathrm{Oz} / \mathrm{acre}$ & $\mathrm{kg} \cdot \mathrm{ha}^{-1}$ & 14.2749 \\
6.8948 & $\mathrm{psi}$ & $\mathrm{kPa}$ & 0.1450 \\
$\left({ }^{\circ} \mathrm{F}-32\right) \div 1.8$ & ${ }^{\circ} \mathrm{F}$ & ${ }^{\circ} \mathrm{C}$ & $\left(1.8 \times{ }^{\circ} \mathrm{C}\right)+32$ \\
& & &
\end{tabular}


objective was to determine whether or not irrigation reduces herbicide injury following the application of terbacil, and to determine the effect of establishment year applications on fruit yield. A secondary objective was to determine whether or not irrigation following terbacil application would affect weed control.

\section{Materials and methods}

Weed control and crop tolerance studies were carried out at the Ohio Agricultural Research and Development Center, Wooster, and on a commercial farm in Fremont, Ohio. Planting was with a mechanical transplanter. Terbacil was applied with a carbon dioxide pressurized backpack sprayer in a volume of $20 \mathrm{gal} / \mathrm{acre}$ and a pressure of $40 \mathrm{psi}$ using flat fan nozzles. We used a randomized complete-block design with a split plot arrangement of treatments. Treatments were replicated six times at Wooster and five times at Fremont. At Wooster the whole-plot treatments were a $2 \times 2$ factorial of irrigation (irrigation immediately after terbacil application or no irrigation), and strawberry growth stage at terbacil application (prior to new growth and at three-leaf stage). Sub-plot treatments were rate of terbacil. At Fremont whole-plots were the two irrigation treatments and terbacil application rate was the sub-plot treatment. Crop stage of growth was not a factor at this site. Approximately $30 \mathrm{~min}$ after terbacil application, the entire field was irrigated with 0.4 inch of water. The no-irrigation treatment was achieved by covering designated plots with plastic tarpaulins before starting irrigation and removing them when the procedure was completed. The experiment did not receive additional irrigation, and there was no rain in the first $48 \mathrm{~h}$ after the plastic was removed. Thereafter irrigation was supplied as needed.

Crop injury was rated weekly after application for 3 weeks using a scale of $1-10$ where $1=$ no injury and 10 = death (Polter et al., 2004). Weed control was rated once, $14 \mathrm{~d}$ after treatment (DAT), using a scale of $1-10$ where $1=$ no weeds observed and $10=$ complete ground cover by weeds. Plots were weeded every $14 \mathrm{~d}$ throughout the experiment with the exception of a 2 -week evaluation period following terbacil application.

Wooster. 'Jewel' strawberry was planted on 14 June 2001. 'Jewel' is considered by growers to be relatively sensitive to terbacil (D. Smith, personal communication). The soil was a Wooster silt loam (fine-loamy, mixed, mesic Typic Fragiudalf, 25\% sand, 50\% silt, $25 \%$ clay) with approximately $3 \%$ organic matter and a $\mathrm{pH}$ of 6.5. Organic matter was determined by the loss on ignition method (Combs and Nathan, 1998). Soil $\mathrm{pH}$ was determined from a $1: 1$ aqueous suspension measured with an Orion $\mathrm{pH}$ meter model 904 (Thermal Electronics, Beverly, Mass.). Herbicides were applied to a single row in a band $10.5 \mathrm{ft}$ long and $4 \mathrm{ft}$ wide. An untreated row separated plots. Data were recorded from the central five plants of each plot. Terbacil was applied at two stages of strawberry growth: Stage $1=$ immediately after planting and prior to new growth, and Stage 2 = at the three-leaf stage. Stage 1 plants were sprayed on 18 June 2001, and Stage 2 plants were sprayed 23 July 2001. Herbicide treatments were terbacil at $0,0.8,1.6,3.2$, and $6.4 \mathrm{oz} /$ acre a.i.. Plant vigor was evaluated 14 May 2002 by visually estimating the percentage of a $1-m^{2}$ quadrat filled by strawberry foliage. Fruit were harvested 17 and 21 June 2002. Marketable fruit, those berries free of disease and blemishes, and unmarketable fruit were separated. Within each category total weight was recorded and a randomly selected sample of 20 berries was weighed individually. A third harvest could not be attained due to extreme heat that caused the plants to shut down and stop producing fruit $\left(91.1^{\circ} \mathrm{F}\right.$ average high temperature 19 to 26 June 2002).

A second trial was initiated with the planting of 'Jewel' strawberry on 3 June 2002. 'Cherry Belle' radishes (Raphanussativus) were seeded l week prior to transplanting strawberry as a weed surrogate to simulate the effect of terbacil and irrigation on annual broadleafweeds. Radishes were seeded [25 May 2002 (Stage 1 plots) and I July 2002 (Stage 2 plots) ] in a 6-inchwide band located 6 inches from each treatment row of strawberry. A subset of those terbacil treatments tested in 2002 , that were deemed to be within the range of rates likely to be registered, $0,1.6$ and $3.2 \mathrm{oz} /$ acre a.i., were applied on 7 June 2002 (Stage 1) and 8 July 2002 (Stage 2). Control of radish was evaluated 7 and 14 DAT. After the final evaluation of weed control, surviving radishes along with other weeds were removed.
Fremont. Strawberry plants were planted 20 May 2001 at a grower's farm in Fremont, Ohio. The cultivar Allstar was used, due to its tolerance of verticillium wilt (Verticillium dabliae), which is abundant at this site. Soil was a Tedrow-Dixboro sandy loam (mixed mesic Aquic Udipsaments X coarse-loamy mixed mesic Aquollic Haplaquolls, 60\% sand, 30\% silt, 10\% clay) with $1.4 \%$ organic matter and $\mathrm{pH}$ of 6.1. Soil organic matter and $\mathrm{pH}$ were determined as previously described for soil from Wooster. Methods of herbicide application and crop maintenance were similar to those of the experiments at Wooster. Plants were sprayed at the three-leaf stage, which occurred 20 June 2001. Sub-plot treatments were terbacil at $0,0.8,1.6,3.2$, and $6.4 \mathrm{oz} /$ acre a.i. Fruit yield was not measured.

Statistical analysis. Data from each trial were individually subjected to analysis of variance (PROC GLM; SAS Institute, Cary, N.C.) and means were separated using least significant difference $(P=0.05)$.

\section{Results and discussion}

Herbicide Tolerance at Wooster. At Wooster, strawberry response to terbacil was most severe 7 DAT. Averaged across treatments, 7 DAT mean injury was 1.8 and 1.6 in 2001 and 2002, respectively. Strawberry plants recovered quickly so that by 21 DAT (data not reported) injury had declined to 1.1 and 1.2 in 2001 and 2002, respectively. This discussion will focus on injury 7 DAT.

Strawberry plants were affected by their stage of growth at the time of terbacil application, by irrigation, and by herbicide rate in 2001 (Table 1 ). Injury was greatest when terbacil was applied prior to new growth (Stage 1) (Table $2)$. This contrasts with results obtained in a previous greenhouse study (Polter et al. 2004) in which strawberry was more tolerant of terbacil applied prior to initiation of visible new growth than that applied at the three-leaf stage. We believe this inconsistency was due, in part, to differences in soils/media in the two studies. Growing media used in the greenhouse study was $33 \%$ milled peat moss with potentially far greater herbicide absorption potential than in the Wooster field soil that contained $3 \%$ organic matter. Terbacil adsorption and immobilization increases in soils as organic matter content increases (Ash- 
Table 1. Analysis of variance probability values for the effect of strawberry growth stage (stage), post-herbicide application irrigation (irrigation) and herbicide application rate (rate) on leaf injury $7 \mathrm{~d}$ following terbacil application at Wooster, Ohio, in 2001 (Trial 1) and 2002 (Trial 2).

\begin{tabular}{lrr}
\hline & \multicolumn{2}{c}{$\begin{array}{c}\text { Analysis of variance } \\
\text { Pvalues }\end{array}$} \\
\cline { 2 - 3 } $\begin{array}{l}\text { Source of } \\
\text { variation }\end{array}$ & $\begin{array}{rr}\text { Trial 1 } \\
(2001)\end{array}$ & $\begin{array}{r}\text { Trial 2 } \\
(2002)\end{array}$ \\
\hline Stage (S) & $0.0095^{*}$ & $0.0019^{*}$ \\
Irrigation (I) & $<0.0001^{*}$ & $<0.0001^{*}$ \\
$\mathrm{~S} \times \mathrm{I}$ & 0.2036 & $0.0448^{*}$ \\
Rate (R) & $<0.0001^{*}$ & $<0.0001^{*}$ \\
$\mathrm{~S} \times \mathrm{R}$ & 0.1517 & $0.0111^{*}$ \\
$\mathrm{I} \times \mathrm{R}$ & $<0.0001^{*}$ & $<0.0001^{*}$ \\
$\mathrm{~S} \times \mathrm{I} \times \mathrm{R}$ & 0.8483 & $0.0283^{*}$ \\
\hline
\end{tabular}

"Indicates significant probability values.

ton and Monaco, 1991). Additionally, greenhouse study plants were potted and sprayed immediately after removal from cold storage; whereas, field study plants were treated $4 \mathrm{~d}$ after planting and new growth probably had been initiated but was not readily visible.

Irrigation immediately following terbacil application reduced injury relative to the non-irrigated treatment (Table 2). The impact of irrigation varied with terbacil rate (Fig. IA). At 0.8 and $1.6 \mathrm{oz} /$ acre injury was reduced $37 \%$ and $39 \%$, respectively; whereas, at 3.2 and $6.4 \mathrm{oz} /$ acre irrigation reduced injury $56 \%$ and $68 \%$, respectively. Injury sustained by irrigated plants was within the acceptable range (i.e., $<2.0$, based upon discussions with commercial strawberry growers) even at the highest rate. Averaged over
Table 2. The effect of strawberry growth stage (growth stage at application), post-herbicide application (post application irrigation), and herbicide application rate (application rate) on leaf injury $7 \mathrm{~d}$ following terbacil application at Wooster, Ohio, in 2001 (Trial 1) and 2002 (Trial 2).

\begin{tabular}{|c|c|c|}
\hline \multirow[b]{2}{*}{$\begin{array}{l}\text { Sources of } \\
\text { variation }\end{array}$} & \multicolumn{2}{|c|}{ Leaf injury $\mathrm{y}^{\mathrm{z}}$} \\
\hline & $\begin{array}{l}\text { Trial 1 } \\
(2001)\end{array}$ & $\begin{array}{l}\text { Trial 2 } \\
(2002)\end{array}$ \\
\hline \multicolumn{3}{|c|}{ Growth stage at application } \\
\hline Stage $1^{y}$ & $2.0 \mathrm{a}^{\mathrm{w}}$ & $1.8 \mathrm{a}$ \\
\hline Stage $2^{\mathrm{x}}$ & $1.6 \mathrm{~b}$ & $1.3 \mathrm{~b}$ \\
\hline \multicolumn{3}{|c|}{ Post application irrigation } \\
\hline Irrigated & $1.2 \mathrm{~b}$ & $1.1 \mathrm{~b}$ \\
\hline Non-irrigated & $2.4 \mathrm{a}$ & $2.0 \mathrm{a}$ \\
\hline \multicolumn{3}{|c|}{ Application rate $\left[\mathrm{oz} / \mathrm{acre}\left(\mathrm{kg} \cdot \mathrm{ha}^{-1}\right)\right]$} \\
\hline 0 & 1.0 & 1.0 \\
\hline $0.8(0.06)$ & 1.4 & n.d. ${ }^{v}$ \\
\hline $1.6(0.11)$ & 1.5 & 1.7 \\
\hline $3.2(0.22)$ & 2.2 & 2.0 \\
\hline $6.4(0.45)$ & 2.9 & n.d. \\
\hline Significance & $\mathrm{L}, \mathrm{Q}^{\mathrm{u}}$ & $\mathrm{L}$ \\
\hline
\end{tabular}

${ }^{2}$ Leaf injury rating scale $1-10$ : rating of $\mathrm{l}=$ no dam age; rating of 1.1 to $2.0=$ acceptable damage; rating of 2.1 or greater $=$ unacceptable damage; rating of 10 $=$ plant death.

'Stage $\mathrm{l}=$ terbacil applied to strawberry plants (dormant crowns) prior to leaf emergence.

${ }^{x}$ Stage $2=$ terbacil applied to strawberry plants at the three-leaf stage.

"Means followed by similar postscripts are not different by the least significant difference test at $P=0.05$. vn.d. = not determined.

" $\mathrm{L}$ and $\mathrm{Q}$ indicate either linear and/or quadratic response at $P=0.05$.

crop stage, injury of irrigated plants never exceeded 1.5 at any rate. When irrigation was withheld after terbacil application, unacceptable levels of injury occurred at 3.2 and $6.4 \mathrm{oz} /$ acre. These results confirm previous results showing that irrigation of 0.4 inch up to $4 \mathrm{~h}$ after application of terbacil at $4.8 \mathrm{oz} /$ acre nearly eliminated injury to greenhouse grown strawberry (Polter et al. 2004).

There was a linear increase in injury symptoms with terbacil rate with data averaged over irrigation treatments (Table 2). Strawberry was relatively tolerant of terbacil at 0.8 and $1.6 \mathrm{oz} /$ acre, receiving injury ratings below 2.0. Foliar injury of this magnitude in grower fields is unlikely to alarm the user or affect yield. Injury increased dramatically with rates of 3.2 and $6.4 \mathrm{oz} /$ acre, averaging 2.2 and 2.9 , respectively.

Results in 2002 were similar to those in 2001. However, irrigation may have had a greater beneficial affect on strawberry tolerance at higher terbacil rates than it did in 2001 (Fig. 1A-B). Overall, 2002 data confirm the observation made in 2001 that strawberry tolerance of terbacil is less when the herbicide is applied $4 \mathrm{~d}$ after planting than when applied at the three-leaf stage. These results are in agreement with Ahrens (1982) who saw more injury when terbacil was applied at 4 oz/acre to strawberry 3 -d after planting than when it was applied 4 weeks after planting. However, even though plants were injured more when terbacil was applied prior to the appearance of new growth than when they were treated at the three-leaf stage, the injury was generally acceptable at either stage when treatment was followed by irrigation (Fig. 2).

Herbicide Tolerance at FreMONT. Irrigated strawberry was significantly more sensitive to terbacil at
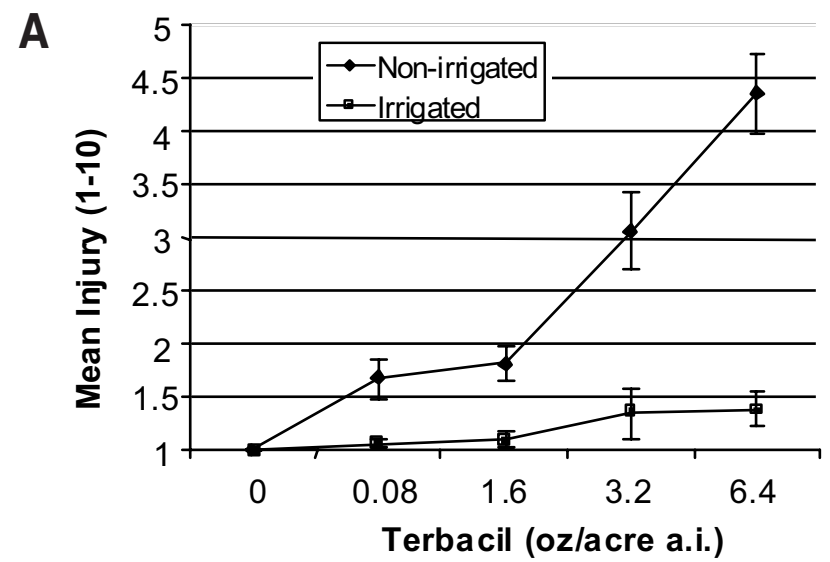

B

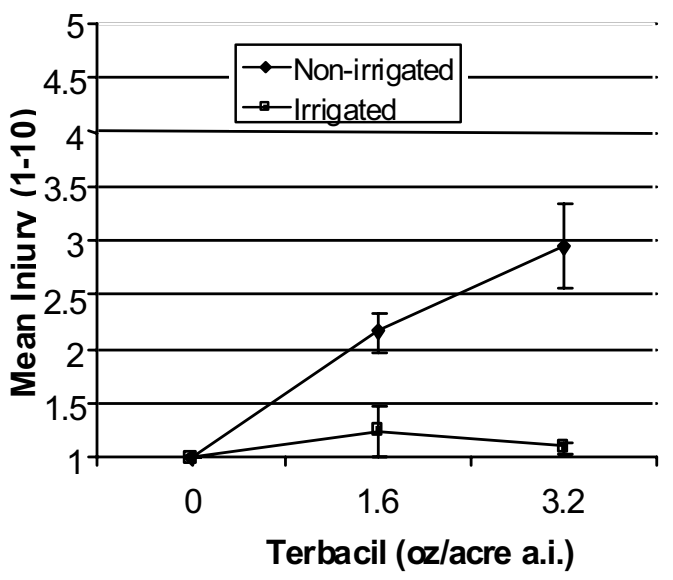

Fig. 1. The effect of irrigation and herbicide application rate on strawberry leaf injury ratings $7 \mathrm{~d}$ following terbacil application: (A, left) Wooster, Ohio, Trial 1 (2001) and (B, right) Wooster, Ohio, Trial 2 (2002). Injury was rated on a scale of 1-10: rating of 1 = no damage; rating of 1.1 to 2.0 = acceptable damage; rating of 2.1 or greater = unacceptable damage; rating of $10=$ plant death $\left(1 \mathrm{oz} /\right.$ acre $\left.=0.0701 \mathrm{~kg} \cdot \mathrm{ha} \mathrm{a}^{-1}\right)$. 


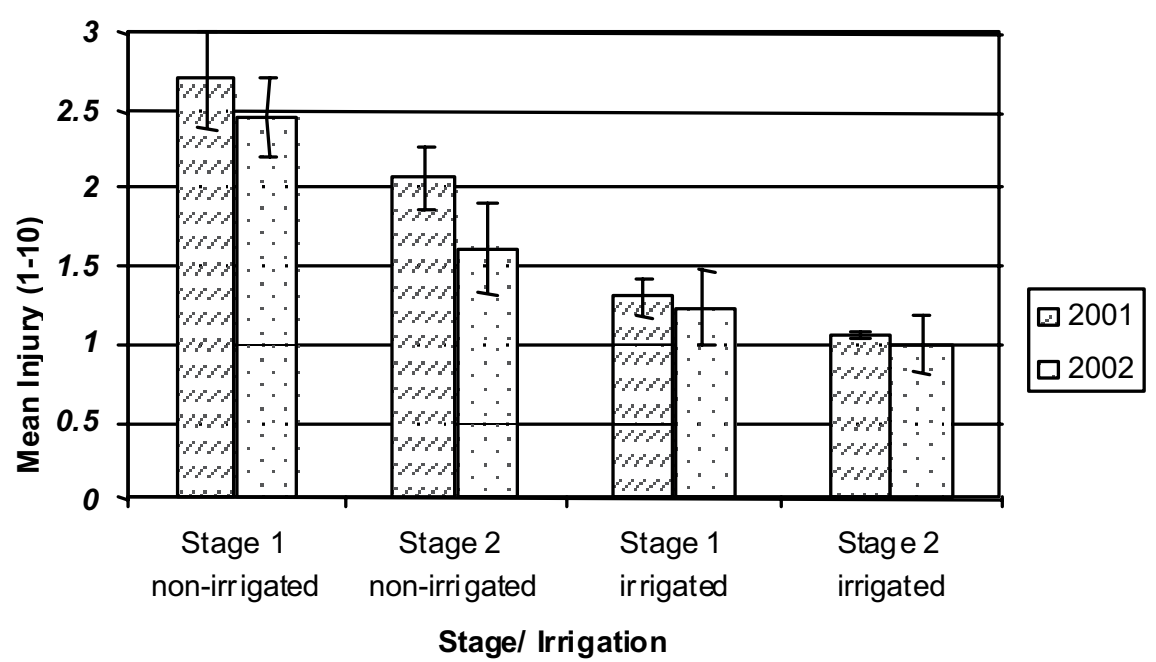

Fig. 2. The effect of post-herbicide application irrigation and strawberry growth stage (Stage $\mathbf{l}=$ herbicide applied immediately after planting and prior to new growth; and Stage 2 = herbicide applied at the three-leaf stage) on leaf injury 7 d following terbacil application at Wooster, Ohio, in 2001 and 2002. Injury was rated on a scale of 1-10: rating of $1=$ no damage; rating of 1.1 to $2.0=$ acceptable damage; rating of 2.1 or greater = unacceptable damage; rating of $10=$ plant death.

Fremont than at Wooster and symptoms of injury developed later. The Tedrow-Dixboro Sandy Loam soil at Fremont contained less organic matter and more sand than the Wooster Silt Loam. We hypothesize that the Tedrow-Dixboro soil has less capacity to absorb the herbicide than the Wooster soil resulting in greater availability of terbacil to the strawberry root system. DuPont Agricultural Products, the registrant of Sinbar, previously advised against its use on soils with less then $2 \%$ organic matter (DuPont, 1992). Root uptake, in contrast to foliar uptake, results in slower but more persistent symptom development (Polter et al., 2004). At Fremont, injury symptoms were greatest 14 DAT in contrast to Wooster where maximum injury occurred 7 DAT.

Main effects of irrigation and herbicide rate were highly significant ( $P=0.0002$ and 0.0001 , respectively). Plants were sprayed only at the threeleaf stage at Fremont. Non-irrigated strawberry was injured more severely than irrigated strawberry (Table 3 ). Injury increased with increasing terbacil rate. The irrigation $\times$ rate interaction was not significant, indicating that irrigation did not reduce injury caused by terbacil to the same degree as it did at Wooster (Figs. 1A-B, 3). We attribute this important result to enhanced terbacil uptake by strawberry roots due to low organic matter and high sand content in the soil.

WeEd control. Weed control (i.e., weed density) at Wooster was affected by terbacil rate and crop stage both years (Table 4). Applied herbicide was less effective when strawberry plants were treated at Stage 2 (three-leaf stage) than when they were treated at Stage 1 (prior to appearance of new growth) (Table 5). By Stage 2 more weeds had germinated and some prominent species upon which terbacil is known to have little activity [e.g., yellow nutsedge (Cyperus esculentus) and quackgrass (Elytrigia repens)] were significant components of the weed community. Yellow nutsedge was not controlled by terbacil and became a problem in 2002 even at the highest application rates. Weed control in response to terbacil rate was generally linear but with a quadratic element at the upper end of the rate range, between 1.6 and $6.4 \mathrm{oz} /$ acre (Table $5)$.

Irrigation did not reduce weed control either year. Also, irrigation did not diminish the control of radishes, when they were used
Table 3. The effect of post-herbicide application irrigation (post application irrigation) and herbicide application rate (application rate) on strawberry leaf injury and weed density $14 \mathrm{~d}$ following terbacil application at Fremont, Ohio.

\begin{tabular}{lcc}
\hline $\begin{array}{l}\text { Source of } \\
\text { variation }\end{array}$ & $\begin{array}{c}\text { Strawberry } \\
\text { leaf } \\
\text { injury }^{\mathrm{z}}\end{array}$ & $\begin{array}{c}\text { Weed } \\
\text { density }^{\mathrm{y}}\end{array}$ \\
\hline Post application irrigation \\
Irrigated & $1.6 \mathrm{~b}^{\mathrm{x}}$ & 4.0 \\
Non-irrigated & $2.3 \mathrm{a}$ & 4.2 \\
Application rate $\left[\mathrm{oz} / \mathrm{acre}\left(\mathrm{kg} \cdot \mathrm{ha}^{-1}\right)\right.$ & $\mathrm{a} . \mathrm{i})$. \\
0 & 1.0 & 6.2 \\
$0.8(0.06)$ & 1.5 & 5.2 \\
$1.6(0.11)$ & 1.8 & 4.0 \\
$3.2(0.22)$ & 2.0 & 3.6 \\
$6.4(0.45)$ & 3.4 & 1.6 \\
Significance & $\mathrm{L}, \mathrm{Q}^{\mathrm{w}}$ & $\mathrm{L}$
\end{tabular}

${ }^{2}$ Leaf injury rating scale $1-10$ : rating of $1=$ no damage; rating of 1.1 to $2.0=$ acceptable damage; rating of 2.1 or greater $=$ unacceptable damage; rating of 10 $=$ plant death

'Weed density rating scale $1-10$ : rating of $1=$ no weeds rating of $10=$ complete ground cover by weeds.

${ }^{x}$ Means followed by similar postscripts are not different by the least significant difference test at $P=0.05$

${ }^{w} \mathrm{~L}$ and $\mathrm{Q}$ indicate either linear and/or quadratic response at $P=0.05$.

as an inter-seeded surrogate weed to monitor seedling weed control $(P=$ 0.64). Polter et al. (2004) also reported effective control of seedling radishes sprayed with terbacil at $4.8 \mathrm{oz} /$ acre followed by overhead irrigation of 0.4 inch of water. Similarly, weed control was not reduced by irrigation treatments administered at Fremont $(P=$ $0.56)$ and was linearly related to rate

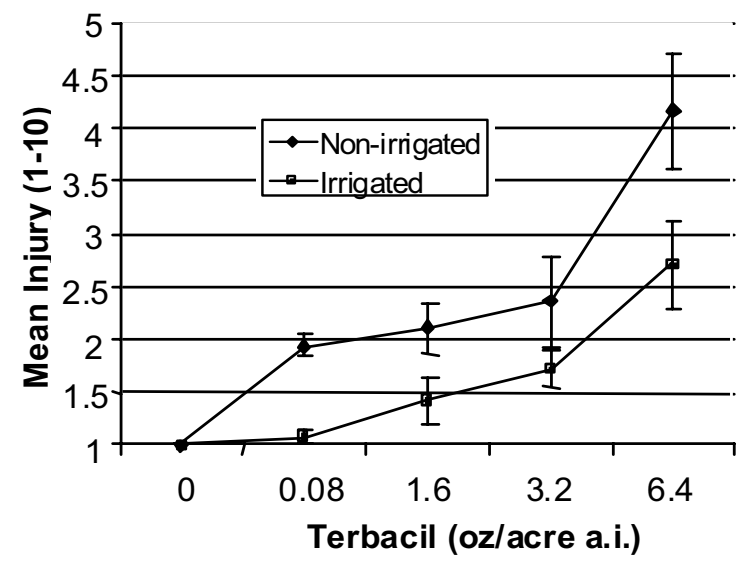

Fig. 3. The effect of post-herbicide application irrigation and herbicide application rate on leaf injury $7 \mathrm{~d}$ following terbacil application at Fremont, Ohio, in 2001. Injury was rated on a scale of 1-10: rating of 1 = no damage; rating of 1.1 to $2.0=$ acceptable damage; rating of 2.1 or greater $=$ unacceptable damage; rating of $10=$ plant death $(1 \mathrm{oz} /$ acre $=$ $\left.0.0701 \mathrm{~kg} \cdot \mathrm{ha}^{-1}\right)$. 
Table 4. Analysis of variance probability values for the effect of strawberry growth stage (stage), post-herbicide application irrigation (irrigation) and herbicide application rate (rate) on weed density $14 \mathrm{~d}$ following terbacil application at Wooster, Ohio, in 2001 (Trial 1) and 2002 (Trial 2).

\begin{tabular}{|c|c|c|}
\hline \multirow[b]{3}{*}{$\begin{array}{l}\text { Source of } \\
\text { variation }\end{array}$} & \multirow{2}{*}{\multicolumn{2}{|c|}{$\begin{array}{c}\text { Analysis of variance } \\
P \text { values }\end{array}$}} \\
\hline & & \\
\hline & $\begin{array}{l}\text { Trial 1 } \\
(2001)\end{array}$ & $\begin{array}{l}\text { Trial 2 } \\
(2002)\end{array}$ \\
\hline Stage $(S)$ & $0.0005^{*}$ & $0.0137^{*}$ \\
\hline Irrigation (I) & 0.2534 & 0.2882 \\
\hline$S \times I$ & 0.3667 & 0.9398 \\
\hline Rate (R) & $<0.0001^{*}$ & $<0.0001^{*}$ \\
\hline $\mathrm{S} \times \mathrm{R}$ & 0.1150 & $0.0046^{*}$ \\
\hline $\mathrm{I} \times \mathrm{R}$ & 0.1592 & 0.6151 \\
\hline $\mathrm{S} \times \mathrm{I} \times \mathrm{R}$ & 0.7836 & 0.9189 \\
\hline
\end{tabular}

Indicates significant probability values.

of terbacil applied (Table 3). Mean weed densities were very low for plots sprayed with terbacil at $6.4 \mathrm{oz} /$ acre and were high for those sprayed with 0 or $0.8 \mathrm{oz} / \mathrm{acre}$. The highest application rate, $6.4 \mathrm{oz} /$ acre, resulted in an $84 \%$ reduction in weed density compared to the control. Weed populations in untreated plots were very high, and mostly consisted of redroot pigweed (Amaranthus retroflexus). Superior weed control achieved at Fremont, relative to Wooster, was probably because less of the herbicide was bound by soil colloids.

STRAWBerRy Vigor and Yield. Strawberry vigor in the spring following terbacil application was not reduced by irrigation $(P=0.2365)$, application rate $(P=0.8161)$ or crop stage $(P=$ $0.2596)$. Plants were very healthy and produced no visible signs of residual herbicide injury. Similarly, yield components were not affected by terbacil application in the establishment year (i.e., probability values associated with stage, irrigation and application rate effects for marketable yield and fruit weight and for unmarketable yield and fruit weight were nonsignificant; data not shown). Approximately $76 \%$ of harvested berries were marketable. The marketable yield per plot averaged $4550 \mathrm{lb} /$ acre; the mean marketable fruit weight was $0.75 \mathrm{oz}$. Our data, indicating a lack of herbicide effect on yield components, are in agreement with those of Weller (1984) who reported that strawberry sprayed immediately after planting with $4 \mathrm{oz} /$ acre of terbacil suffered no reduction
Table 5. The effect of strawberry growth stage (growth stage at application), post-herbicide application irrigation (post application irrigation), herbicide application rate (application rate), and weed density $14 \mathrm{~d}$ following terbacil application at Wooster, Ohio.

\begin{tabular}{|c|c|c|}
\hline \multirow[b]{2}{*}{ Effects } & \multicolumn{2}{|c|}{ Weed density $^{\mathrm{z}}$} \\
\hline & $\begin{array}{l}\text { Trial I } \\
(2001)\end{array}$ & $\begin{array}{l}\text { Trial 2 } \\
(2002)\end{array}$ \\
\hline \multicolumn{3}{|c|}{ Growth stage at application } \\
\hline Stage $1^{\mathrm{y}}$ & $1.1 b^{w}$ & $1.8 \mathrm{~b}$ \\
\hline Stage $2^{x}$ & $3.4 \mathrm{a}$ & $2.4 \mathrm{a}$ \\
\hline \multicolumn{3}{|c|}{ Post application irrigation } \\
\hline Irrigated & 2.6 & 2.2 \\
\hline Non-irrigated & 2.0 & 2.0 \\
\hline \multicolumn{3}{|c|}{ Application rate $\left[\mathrm{oz} /\right.$ acre $\left(\mathrm{kg} \cdot \mathrm{ha}^{-1}\right)$ a.i. $]$} \\
\hline 0 & 3.8 & 2.8 \\
\hline $0.8(0.06)$ & 1.9 & n.d. ${ }^{v}$ \\
\hline $1.6(0.11)$ & 2.0 & 1.8 \\
\hline $3.2(0.22)$ & 1.7 & 1.7 \\
\hline $6.4(0.45)$ & 2.0 & n.d \\
\hline Significance & $\mathrm{L}, \mathrm{Q}^{\mathrm{u}}$ & $\mathrm{L}, \mathrm{Q}$ \\
\hline \multicolumn{3}{|c|}{$\begin{array}{l}\text { "Weed density rating scale } \mathrm{l}-10 \text { : rating of } \mathrm{l}=\text { no weeds; } \\
\text { rating of } 10=\text { complete ground cover by weeds. } \\
\text { yStage } \mathrm{l}=\text { terbacil applied to strawberry plants (dormant } \\
\text { crowns) prior to leaf emergence. } \\
\text { 'Stage } 2=\text { terbacil applied to strawberry plants at the } \\
\text { three-leaf stage. } \\
\text { "Means followed by similar postscripts are different by } \\
\text { the least significant difference test at } P=0.05 \text {. } \\
\text { "n.d. }=\text { not determined. } \\
\text { "L and } Q \text { indicate either a linear and/or quadratic } \\
\text { response at } P=0.05 \text {. }\end{array}$} \\
\hline
\end{tabular}

in plant stand and had increased yield compared to non-treated plants.

\section{Conclusion}

Our data and those of others (Ahrens, 1982) suggest that foliar injury may result from terbacil applied to strawberry at very early stages of growth (e.g., immediately following planting). However, applications at these early stages of growth are also more likely to result in effective weed control than when terbacil is applied after strawberry growth has advanced. As terbacil is most active against germinating seeds and very young seedlings, its effectiveness as a weed control treatment can be substantially reduced by delays in application or incorrect timing of application. The potential for weeds to quickly reach levels of infestation that would otherwise require hand weeding and cultivation makes early application of herbicide of primary importance. Sinbar is now labeled for use on newly planted strawberry at $2-3 \mathrm{oz} /$ acre of product. In our experience most summer annual weeds are controlled with these rates; however, some hand weeding and cultivation will always be required to control escapes. The temporary injury from early applications of terbacil did not cause sustained reduction in vigor or reduction in yield in our experiments. The combination of low rates of terbacil used in our studies (1.6-3.2 oz/acre), applied to healthy plants growing under minimal stress and followed immediately by irrigation is a safe option that growers can use to improve weed control and reduce hand weeding costs in the planting year.

\section{Literature cited}

Ahrens, J.F. 1982. Napropamide and terbacil for newly planted strawberries. Adv. Strawberry Prod. 1:22-26.

Ashton, F.M. and T.J. Monaco. 1991. Weed science: Principles and practices 3rd ed. Wiley, New York.

Barrentine, J.L. and G.F. Warren. 1970. Isoparaffinic oil as a carrier for chlorpropham and terbacil. Weed Sci. 18:365-372.

Combs, S.M. and M.V. Nathan 1998. Soil organic matter, p. 53-58. In: Recommended chemical soil test procedures for the North Central Region. NCR Publ. No. 221. Missouri Agr. Expt. Sta., Columbia.

DuPont. 1992. Sinbar herbicide for weed control in strawberries, product label. E.I. Du Pont De Nemours and Co., Agr. Products, Wilmington, Del.

Huffman L. 1999. Herbicide injury symptoms in berry crops. Ontario Ministry of Agr. and Food. 6 June 2004. <http://www. gov.on.ca/OMAFRA/english/crops/ facts/berry_injury.htm\#24d>.

Lindstrom, J.T. and H.J. Swartz. 1987. Strawberry genotype responses to terbacil. Adv. Strawberry Prod. 6:44-46.

Masiunas J.B. and S.C. Weller. 1986. Strawberry cultivar response to postplant applications of terbacil. HortScience 21(5):1147-1149.

Pritts, M.P. and D. Handley. 1998. Strawberry production guide for the Northeast, Midwest, and eastern Canada. NRAES-88. Northeast Reg. Agr. Eng. Serv., Ithaca, N.Y.

Polter, S.B., D. Doohan, and J.C. Scheerens. 2004. Tolerance of greenhousegrown strawberries to terbacil application as influenced by cultivar, plant growth stage, application rate, application site and simulated post-application irrigation. HortTechnology 14(2):223-229.

Weller, S.C. 1984. Evaluation of postplant applications of terbacil and napropamide to strawberry plants. Adv. Strawberry Prod. 3:15-19. 